\title{
Rett syndrome: Methyl-CpG binding protein 2 transformation and phenotypic- genotypic characteristics
}

\author{
Asma Saeed, Muhammad Farhan Nasir and Tanveer Hussain* \\ Department of Molecular Biology, Virtual University of Pakistan \\ *Corresponding author's email: tanveer.hussain@vu.edu.pk \\ Citation \\ Asma Saeed, Muhammad Farhan Nasir and Tanveer Hussain. Rett Syndrome: Methyl-CpG Binding Protein 2 \\ Transformation and Phenotypic-Genotypic characteristics. Pure and Applied Biology. Vol. 9, Issue 4, pp2318-2329. \\ http://dx.doi.org/10.19045/bspab.2020.90246
}

Received: 25/03/2020

Revised: $30 / 05 / 2020$

Accepted: $18 / 06 / 2020$

Online First: 08/07/2020

\section{Abstract}

Methyl-CpG-binding protein 2 (MECP2) mutation has been coupled to Rett syndrome; X-linked neurological disorder, leading to steady slowing down of neurodevelopment that exclusively affects girls worldwide. As this gene is known for its specific localization and careful binding to methylated Cytosine residues in genomic DNA and is expected to intercede biological function of transcriptional oppression and chromatin concentration too. But a finest delivery of properly folded and tailored MECP2 protein is required for its part in directive gene transcription. The detailed research work done worldwide shows that MECP2 function is not only vital for normal brain development and neuronal pledge but is eventually requisite for establishment and upholding of normal neuronal occupation. The percentage of MECP2 mutation in classic Rett patients is up to $80 \%$ however this transformation spectrum ranges from severe to mild with congenital encephalopathy, mental retardation and various neurological side effects. Altered MECP2 shows relevance to phenotypic manifestation but the skewed $\mathrm{X}$ inactivation appears to influence its seriousness in a far more extensive sense. The patients with identical MECP2 mutation may show very different phenotypic features and strictness because of variation in $\mathrm{x}$-inactivation prototype among individuals. This study is done to review the availability of diagnosis and treatment at molecular level. In this review the clinical spectrum and molecular findings in females with MECP2 dysfunctions are also reviewed with special reference to evaluate the sufficient available criteria for molecular diagnosis and treatment across the globe.

Keywords: Genotype; MECP2 mutation; Phenotype; Rett syndrome Introduction

Rett is an X-linked dominant neurodevelopmental syndrome, cause severe intellectual disability predominantly among girls. Hereditary changes of MECP2 known as methyl- $\mathrm{CpG}$ binding protein 2, is prime reason of Rett. Neurological disorders are associated with varied medical manifestations inclusive of harshness of diseases, age, prognosis and cure. Due to the heterogeneity and sundry classes of neurological disorder, some are brought about by single locus while for other's disease disposition is heterogeneous in nature resulting from interaction between genetic as well as environmental factors. According to researchers [1, 2] genomic variations play a significant role in disease vulnerability and 
treatment options [3]. In this regard, some of molecular methods are under exploration for adjustment of mutant and freak genes and their regulation $[4,5]$.

Among neurodevelopmental syndrome, Mental Retardation (MR) is base of most serious handicap children as well as young ones. Mental retardation (MR) from modest to severe that is less than 50 is likely to influence $0.3-0.5 \%$ of inhabitants and frequency increases to $1-1.5 \%$ if mild MR is considered, but approximations swing extensively among pandemic studies. Genetic causes are tremendously heterogeneous include noticeable chromosomal anomalies and monogenic diseases [2]. In the Online Mendalian database more than 1000 entries with 282 genes recorded with retardation but $25-40 \%$ of severe cases remain unexplained and studies show that numbers of instances in all likelihood involve combinations of multigenic and surrounding elements [6-9].

\section{MECP2 structure and functional units}

Basically MECP2 is the most expressly DNA-binding protein positioned in chromosome Xq28 on distal portion of long arm and tied in 5-methyl-cytosine, e.g. Figure
$1[7, \mathbf{1 0 - 1 2}]$. It is a founder member protein that binds to methyl $\mathrm{CpG}$ domain, consist of single polypeptide that compose of $\mathrm{CpG}$ proteins and a transcription repression domain. It is likewise proficient of binding to 5-methyle cytosine residues to distinct correspondence methylated $\mathrm{CpG}$ dinucleotides both in naked DNA as well as within chromatin in mammalian genome [13]. It is comprises of four exons in which exon 3 is the biggest one, spans 1084 base pairs and encoding 486 amino acids, holds two functional domains; 84 aa Methyl CpGrestricting Domain and 104 aminoacids Transcription repression domain. Basically MECP2 encodes two key isoforms MECP2$\mathrm{E} 1$ and E2. Exon 2 is joined with MECP2-E1 and initiate translation, ensuing in a diverse $\mathrm{N}$-terminal end at exon 1 . The two isoforms are identical in both domains [14]. Initially the MBD ties to cytosine deposits residues symmetrically to $\mathrm{CpG}$ dinucleotides situated at promoter site and later on facilitate transcriptional silencing after the completion of DNA methylation [15]. The TRD interacts with histone deacetylase and SIN3A and interaction causes deacetylation of core histones follow-on transcriptional repression.

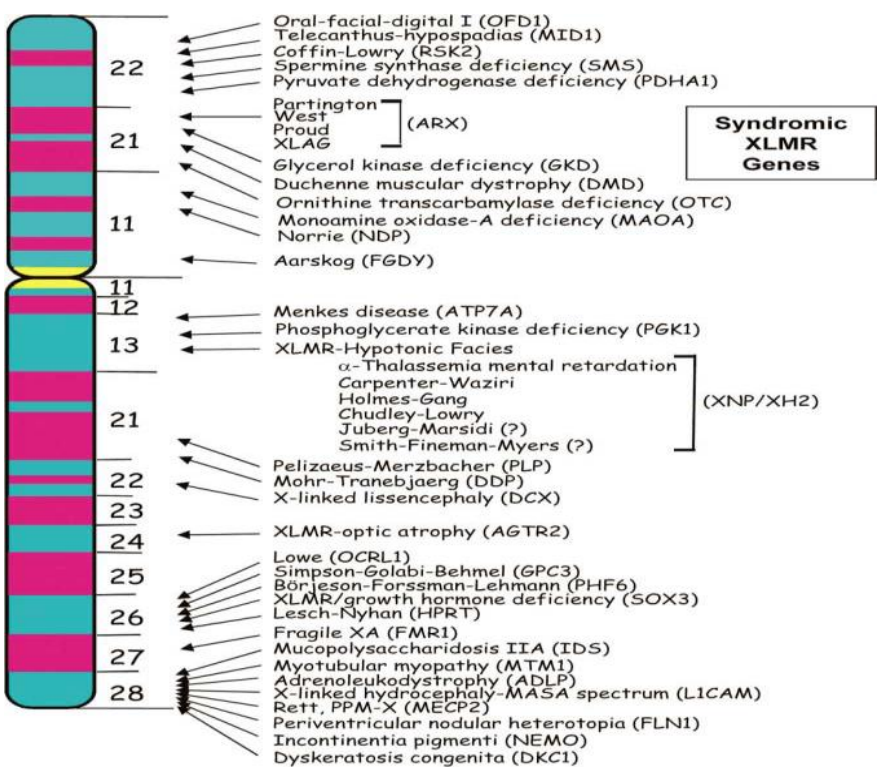

Figure 1. Here is the graphical representation of the chromosome contain MECP2 gene [7] 


\section{Risk factors}

Hereditary and non-hereditary components contribute similarly and equally for MECP2 mutation. Non-genetic factors incorporate nutritional and environmental factors, poisonous exposure at some stage in pregnancy and some of socio-economic factors for example; level of income, own family situations and cultural surroundings ought to be a contributory role in prevalence of neuro developmental illnesses. The phenotypic articulation of Rett is Xinactivation pattern which is an ordinary and random process in females because one $\mathrm{X}$ chromosome is turned off. Females have equal number of paternal as well as maternal active $\mathrm{X}$ chromosome and in rare cases show nonrandom or skewed inactivation (XCI). This pattern can significantly impact phenotypic characteristics, bringing about a varied degree of severity such as a normal MECP2 gene to an extreme abnormal atypical Rett syndrome whenever altered gene is active [16].

A choicest degree of efficiently folded and tailor-made MECP2 is mandatory for its role in instruction of transcription and either slight or a lot may result with pathogenic penalty [17]. Consequently disturbance of the supply in nucleus via defective co/ post-translational $\mathrm{N}$-terminal modification leads to sooner degradation and can cause deregulations of many other genes, ultimately leads to Rett phenotype [14].

\section{Causes}

A genetic change of MECP2 gene causes Rett [18]. MECP2 related disorder is from rising class of genetic diseases and over 200 known mutations in Rett are because of defects in epigenetic regulation. However the mutations in a particular gene aren't definitive for the diagnosis of Rett but $95 \%$ of diagnosed individuals have been observed with mutations inside the gene encoding transcriptional regulator [19]. The excessive recurrence of cytosine to thymidine transitions shows that the deamination of methylated cytosines is not an unusual purpose of Rett whilst spontaneous deamination is likely to make a contribution to the high frequency of methyl-cytosine transitions to thymidine. Number of elements has been observed to accelerate deamination, such as, cytosine protonation because of unusual base pair formation or modification [20].

Almost $80 \%$ of MECP2 mutation present in exon 3 [21]. To give bit of knowledge about mutated MECP2 locus [22] looked into 48 girls with classical sporadic Rett, seven families with conceivable familial genetic changes and five sporadic with mild phenotypic characters, however no longer diagnostic for Rett. They used Long Distance PCR and Long-read Direct Sequencing techniques to sequence the coding regions. In all instances of recognized mutations, fortyfour out of fifty-five had been classical sporadic or familial Rett sufferers and just $20 \%$ cases were non-demonstrative highlights. Additionally they found considerably few symptoms in cases hauling missense mutations as compare to those with nonsense and framshift (truncating) mutations [23].

Sixty-five to 80 percent of Rett sufferers have mutations in exon 3 or 4 in related gene. In spite of enormous number of changes distinguished, eight very commonplaces i.e. R106w，R133c，T158m， R168x， R255x, $\mathrm{R} 270 \mathrm{x}, \mathrm{R} 294 \mathrm{x}$ and R306c represent dominant part of transformation in girls [16, 24].

In this era of molecular diagnosis the exact mechanism with the aid of which MECP2 dysfunction causes Rett Syndrome is obscure; however mounting proof indicates that neuronal fitness and improvement rely upon precise law of MECP2 expression [25]. Examination of brain uncovers profound microencephaly, densely packed neurons, neuronal dystrophy in cerebral cortex and reduction in dentritic arborization [18]. 
Accordingly heterozygous mutant girls show mosaic pattern for MECP2 deficiency with huge variety of phenotype while guys progressively demonstrate severe phenotypes and rarely live beyond 2 years. So by the age of 4-6 weeks, progressive physical deterioration starts and individual typically die at $\tilde{10-12}$ weeks. In addition, neurons of Rett people seem to demonstrate a decrease in dentritic maturity. Furthermore, dentritic arborization and dentritic back bone density is decreased in several brain regions as well [26-28].

Generally cerebrum size can be reduced by as much as $34 \%$. Young Rett sufferers have expanded thickness of GABA receptor inside the caudate that reduces with age such as ionotropic glutamate receptor .i.e. AMPA and NMDA are uniquely decreased in basal ganglia in patients of more than eight years old [19, 29]. Ubiquitously expressed MECP2 mutation, leads to various phenotypes and its incidence ratio in males is $1-2 \%$ only and usually leads to lethality [30].

Basically Rett syndrome is evolved in four typical tiers. First degree is stagnation period with onset between 6-18 months and lasts weeks to months and is characterized by formative capture without relapse. Second stage begins among 1-4 years old and is described by way motor and language skills. Stage 3 is pseudostationary can also takes place for a considerable length of time where patients may improve communication but motor function get worsen. In stage four, loss of ambulation is observed however there is no abrupt progress from one to other stage [31, 32].

Globally lot of research work is done on genetic causes of Rett such as [33] presented mutation heterogeneity in Salvic population in 2007 and identified 78.16\% classic Rett patients. The transversion 323>A in exon 3 prompts substitution of Lysine to Histidine at function 108 , lies within MBD and affect methyl specific binding [34]. At position 302 the $904>\mathrm{T}$ change causes substitution of proline with serine ought to meddle with get together of transcription silencing complex, cancelling connection with Sin3A corepressor and histone deacetylase recruitment. The framshift mutations in exon three that are 189-190delGA deletion with threonine at position 63 and another missense mutation of $17 \mathrm{bp}$ deletion $816-832$ del17 in TRD makes stop codon. A mixed cancellation /reversal change 1063-1236del; 1189-1231inv 43 became additionally affirmed by cloning of influenced vicinity of methyl binding proteins. Majority of missense changes have been positioned in MBD while nonsense situated from end part of MBD to TRD and cancellations were generally found for most part in C-terminal place. The eight most regular changes i.e. $316 \mathrm{C}>\mathrm{T}, 397>\mathrm{T}, 473 \mathrm{C}>\mathrm{T}, 502>\mathrm{T}, 763 \mathrm{C}$ $>\mathrm{T}, \quad 808 \mathrm{C}>\mathrm{T}, \quad 880 \mathrm{C}>\mathrm{T}, \quad 916 \mathrm{C}>\mathrm{T}$ representing for greater than half of Rett located at $\mathrm{CpG}$ [35].

\section{Prevalence}

Rett syndrome initially was perceived as a neural disease in 1966 by Austrian pediatrician Andreas Rett and after the dynamic work on this disease it was recognized as genetic disorder in 1982 worldwide, e.g. Table 1 and most common reasons of mental retardation among women $[25,36,62]$. Rett syndrome (RS) common features are normal psychomotor advancements until first six months of life accompanied via cognitive impairment, lack of satisfactory and gross motor skills, lack of communicative abilities and acquired microcephaly. Individuals with Rett ordinarily reach into middle age and they will continue to exist even longer [28, 37]. This neurodevelopmental disorder had an expected prevalence of 1 in 10,000-15,000 girls beginning with maximum cases being sporadic [38, 39].

Because of the high proportion of consanguinity in Asian countries the 
prevalence of neurodevelopmental disorder is three folds higher in underdeveloped countries as compare to Western countries [40]. Consanguinity is an important aspect to determine the birth defects including intellectual disability with relatively high prevalence of autosomal recessive forms. Consanguineous marriage is defined as a relationship between two persons having common ancestor [41]. According to a report $201110.4 \%$ of all marriages crop up in family worldwide while its fraction is much higher in Arab and central Asian population. In Pakistan its rate is $>60 \%$ with $17-38 \%$ as firstcousin marriages [42].

Table 1. Across the world Rett prevalence from 1982 to 2006 [62]

\begin{tabular}{|c|c|c|c|c|c|}
\hline Country & $\begin{array}{c}\text { Study } \\
\text { Year }\end{array}$ & $\begin{array}{c}\text { Classification of } \\
\text { Rett syndrome } \\
\text { cases }\end{array}$ & $\begin{array}{c}\text { Prevalence } \\
\text { per 10,000 } \\
\text { females }\end{array}$ & $\begin{array}{c}\text { Prevalence } \\
\text { 95\% Cl }\end{array}$ & Age range \\
\hline Southwest Sweden & 1982 & Classical just & 0.65 & $0.25-1.05^{*}$ & $6-17$ \\
\hline West Scotland & 1982 & Classical just & 0.69 & $0.41-0.99^{*}$ & $3-15$ \\
\hline Southwest Sweden & 1982 & Classical just & 0.84 & $0.38-1.30^{*}$ & $6-17$ \\
\hline Switzerland & $1967-1982$ & Classical just & 0.41 & $0.25-0.56^{*}$ & $4-19$ \\
\hline Northern Italy & $1973-1983$ & Classical just & 22.03 & $7.2-51.3 *$ & $4-12$ \\
\hline Tokyo, Japan & 1988 & Classical, atypical & 0.50 & $0.32-0.68$ & $6-14$ \\
\hline North Dakota, USA & 1989 & Classical just & 0.53 & $0.06-0.96$ & $0-18$ \\
\hline Northern Tuscany & $1978-1990$ & Classical, atypical & 2.1 & $0.04-4.16$ & $3-14$ \\
\hline Furkui prefecture & 1993 & Classical just & 0.22 & $0.05-1.13 *$ & $6-14$ \\
\hline Estonia & 1993 & Classical just & 0.66 & $0.24-1.07 *$ & $0-15$ \\
\hline Australia & 1994 & Classical, & 0.67 & $0.55-0.79$ & $5-18$ \\
\hline Norway & 1995 & Classical, atypical & 2.17 & $1.87-2.59^{*}$ & $3-19$ \\
\hline Taxas, USA & 1990 & Classical, atypical & 0.58 & $0.36-0.53$ & $2-18$ \\
\hline France & 2004 & Mutative positive & 0.58 & $0.51-0.66$ & $4-15$ \\
\hline Australia & 2004 & Classical, atypical & 0.88 & $0.83-93$ & $5-18$ \\
\hline Hong Kong West & 2006 & Classical just & 0.57 & $0.15-0.98$ & $\leq 35$ \\
\hline
\end{tabular}

*Confidence intervals were not presented in Australia in 2004 but data was calculated given in article

\section{Diagnosis}

The diagnosis in $\mathrm{MR}$ requires multidisciplinary exertion yet investigation begins with parental record that mainly includes tetragenic exposure such as alcohol, cigarette and drugs [43]. Maternal illnesses together with myotonic dystrophy, pregnancy history, amniotic liquid sum and fetal utero hypotonia are also taken into account. Family ancestry provides important insights for MR, such as miscarriage provide evidence for $\mathrm{X}$ connected impediments as well as psychological signs may be considered in patient diagnosis. American College of Medical Genetics recommendations are presented for screening of 20-29- metabolic disorder in newborn. Physical examination highlights mainly center around assessment of dysmorphic neurological abnormalities and behavioral phenotype, for example, hand-wringing of Rett patients. Magnetic Resonance Imaging (MRI) indicates cranial shape variations such as microcephaly, macrocephaly and neurological 
manifestation. Molecular testing is also a useful diagnostic tool for prenatal analysis for family. Variability in diagnosis is based on differing populace based investigation, age of patient and the time of study [44-46].

Modern mutation detection assays analysis show $97 \%$ of individuals with typical Rett. So a consortium was established in 2006 by experts from 13 different countries to address the confusion regarding diagnosis of Rett by the collaboration of International Rett Syndrome Association (IRSA). At present it is supported by International Rett Syndrome Foundation, an emerged foundation established by collaboration of IRSA and RSRF Rett Syndrome Research Fund [47]. As per IRSA, main criteria of primary Rett are incomplete and complete loss of hand aptitude, verbally expressed language and impaired gait abnormalities. Exclusion criteria for a typical Rett: neurometabolic disease due to severe infection, hideously strange psychomotor progress in first 6 months of life, precariousness in breathing, bruxism when conscious, impaired rest patterns, irregular muscle tone, fringe vasomotor unsettling influences, scoliosis/kyphosis, development hindrance and undersized cold hands and feet, illadvised giggling/ spells, decreased reaction to torment, and extreme eye dispatch [48]. In 2005 team of scientists, exhibited the characteristic testing and learning on genotypic-phenotypic relationship of recognized transformation with extraordinary weight on their importance to far reaching screening programs in presymptomatic people. According to them testing measures should be readily valid, technically straightforward and consistent with high detection speed, the most minimal conceivable recurrence of lowest possible frequency of false-negative and false-positive outcomes [39].

Pre-birth screening is structured at distinguishing pregnancies at expanded dangers of inborn or chromosomal variation from a norm utilizing a noninvasive methodology, for example, investigation by biochemical markers in maternal serum and ultrasound finding to spot fetuses with transformation. However the invasive diagnostic procedure includes; check the level of alpha-fetoprotein to find out the risks of neural cylinder and imperfections of ventral wall, pregnancy related plasma protein A (PAPP-A) $\beta$-human chorionic gonadotrophin joined with extended nuchal translucency on ultrasonography. It is also essential that all prenatal diagnosis must be gone before by non-directive hereditary advising and educated assent or informed consent.

An invasive prenatal diagnostic procedure (DNA-based mutation analyses) should offer to the parents of an infant with Rett syndrome and an identified MECP2 change that has an estimated approximately $1 \%$ recurrence rate. A thorough pedigree and careful history to identify the family members at risk are also vital.

\section{Treatment}

Henceforth, this field does not have a live human model that give endless supply of neurons so investigation could be executed in controlled circumstances. In addition, hardened tissues portions are of constrained use for neural system. Brain imaging does not allow studying subtleties of short hardware in cerebrum. Indeed, even creature models frequently do not reiterate complex human ailments. In 2012, team of scientists [49] created human neurons from somatic cells by induced pluripotent stem cell (iPSC) technology. They reprogrammed substantial cells into pluripotent position by over exploitation of explicit genes. Isogenic pluripotent cells (iPSC) demonstrated striking and comprehension of multifaceted illnesses with heritable and sporadic setting. On account of the high fraction of consanguinity in Pakistani population, 
Homozygosity mapping is a perfect system to distinguish mutated genes responsible for Non Syndromic Autosomal Recessive Intellectual Disability (NS-ARID). Ultimately, this would be helpful to screen transporters so as to diminish quantity of influenced babies in a family [50].

The system used to display Rett disorder, utilizing mutated female patients with $\mathrm{X}$ connected influenced genes as the age of isogenic cell lines had the advantage of $\mathrm{x}$ inactivation in iPSC clones that hold freak just as wild-type. However, challenges are greater where mutations are unknown because of sporadic cases $[51,52]$. In their investigation, they got neurons from Rett iPSC conveying four assorted MECP2 changes with a few adjustments in contrast to five non-affected people, for example, reduced soma measure, and altered dentritic spine mass and compact neurotransmitters.

Besides, to demonstrate causality, these phenotypes were endorsed against MECP2 in increase and loss of limit preliminaries utilizing wild type MECP2 cDNA and particular shRNA. Most importantly, these cellular defects were approved via self sufficient groups, revealing the qualities and reproducibility of the framework and in like manner prepared to save the deformilities in the quantity of glutamatergic synapses [53] by two competitor drugs Insulin-like Growth Factor1 and gentamicin. The former one is reviewed as possibility for pharmaceutical treatment of Rett and potential issues of persistent clinical fundamentals while gentamicin was additionally accustomed to ensure neurons having a nonsense MECP2 alteration by raising its protein level [54-56]. The iPSC system offers some of confinements; cells in culture represent research artifacts that may miss or overestimate the important signaling information, mask possible cellular phenotypes or can create artificial ones. To overcome the other challenges of the descent of the relevant neuronal subtypes, unambiguous reporter genes need to be used with further optimization setup [57, 58].

In 2013, Chapleau and colleagues reviewed specific aspects of treatment plan based on clinical trials with already accepted US-FDA approved medication. Nutritional issues were a highlighted in the treatment of Rett as $25 \%$ of patients feed by gastrostomy to meet high metabolic demands of body but was a difficult decision for caregivers. Gastrointestinal issues including constipation and gastroesophageal reflex could be treated by polyethylene glycol 3350 or milk of magnesia. Moreover esophageal irritation and acid secretion prevented by use of $\mathrm{H} 2$ receptor blockers or protein pump inhibitors. The use of antiepileptic drug lamotrigine had been shown to be profoundly successful in looking after seizures. Another approved drug for its affects on motor dysfunction was the opiate antagonist naltrexone. The aminoacids derivate L-carnitine was found to be useful in rest support and to improve correspondence capacity. Folate supplementation was proposed in Rett for a number of reasons because of its capacity to methylate segments of DNA. But results and findings of the study presented essential considerations for future clinical trials such as disease rigorousness, age and mutation type that would offer great impact on data analysis $[28,59]$.

\section{Discussion}

The detailed review of the research work done worldwide shows that MECP2 function is not vital for normal brain development and neuronal vow although is required for institution and continuance of normal neuronal function. Some definite aspect of neural maturation for which MECP2 is required remain to be determined [60].

It is important to take note of that because of verity in $\mathrm{X}$-inactivation design in females with same MECP2 mutation may has diverse phenotypic highlights and severity and 
believed that these modifications are influenced probands acquired from nonpenetrant guardian are very conceivable for MECP2. Among variations distinguished either because of rehash extends bringing about length changes of polyanaline, missense mutations or regions just upstream of the start codon along these lines possibly influencing the capacity just as the articulation of neurological issue [61].

This is not amazing as run of the mill patients can be either pretty much seriously influenced than classical patients. In this way, it is trusted that medicinal region would probably get familiar with the trial of counseling, development and valuable assessment of kids distinguished by presymptomatic screening if a quicker and less expensive test winds up available [39]. The currently used diagnostic tests will have to be improved and new psycho-diagnostic tests should be created to calibrate the distinctive parts of cognitive processes in patients with mental retardation linked with $\mathrm{X}$ chromosome. The genotypic-phenotypic studies at present will offer point by point physical neurological examination and used to incorporate extra knowledge about possible mechanisms involve in cognition, learning behavior and brain development. Moreover this study would highlight dimensions to be improved among molecular techniques and tools such as, biochemical analysis, neuropsychological and behavioral testing, joined with Electroencephalography, Computerized Tomography or Magnetic Resonance Imaging and Single-photo Emission Computed Tomography Imaging of brain [30].

A definitive likely profit by unfavorable le finding and treatment is a standpoint amongst the most basic thought range from sparing the lives of influenced infants to improve their prognosis, excellence of life and neurodevelopment. Furthermore, the screening must be cost compelling, helpful and extensively available from general wellbeing perspective. Based on these particular standards criteria for testing would be fulfilled some but not from all aspects of child testing. The ordinaries of Rett disorder is of around 10,000-15,000 females makes it a sufficiently noteworthy problem to justify open fixation worldwide [39].

\section{Conclusion}

In human neuronal maintenance and maturation is disturbed by a kind of alteration in methyl-CpG binding protein 2 shortly known as MECP2 and leads to Rett syndrome. This MECP2 gene mediates transcriptional repression and chromatin condensation because of the methylated Cytosine residue binding to genomic DNA. Since yet, there are no obvious treatments available. So universal newborn or prenatal screening is a big challenge in this modern era, until then secondary genetic testing and other warning signs based on behavior should be preferred substitutive approaches for this purpose. Though preclinical research on creature models of Rett syndrome makes the presymptomatic testing worthwhile but prenatal diagnosis in females with a family record is noticeable. Great care need to be exercised in this diagnostic and counseling domain as it raises sensitive ethical issues. A comparative view on the research work has done worldwide highlights its importance as a serious genetic disease. That is why; to devise targeted therapeutic strategies for Rett patients is ultimate goal and a step closer to complete the whole picture. All in all consanguineous carrier screening would create opportunities to discover disease causing mutations, thus providing huge benefit to families, communities and to public health.

\section{Authors' contributions}

Conceived and designed the experiments: $\mathrm{T}$ Hussain, Performed the experiments: MF Nasir, Analyzed the data: A Saeed \& T Hussain, Contributed materials/ analysis/ 
tools: A Saeed, MF Nasir, Wrote the paper: A Saeed, MF Nasir \& T Hussain.

\section{References}

1. Zahorakova D, Rosipal R, Hadac J, Zumrova A, Bzduch V, Misovicova N \& Martasek P (2007). Mutation analysis of the MECP2 gene in patients of Slavic origin with Rett syndrome: novel mutations and polymorphisms. J Hum Genet 52(4): 342-348.

2. Sirianni N, Naidu S, Pereira J, Pillotto RF \& Hoffman EP (1998). Rett syndrome: confirmation of X-linked dominant inheritance, and localization of the gene to $\mathrm{Xq} 28 . A m \quad J$ Hum Genet 63(5): 1552.

3. Foo JN, Liu J, \& Tan EK (2013). Nextgeneration sequencing diagnostics for neurological diseases/disorders: from a clinical perspective. Hum Genet 132(7): 721-734.

4. Bowers WJ, Breakefield XO, \& SenaEsteves M (2011). Genetic therapy for the nervous system. Hum Mol Genet 20(R1): R28-R41.

5. Shahbazian MD, Antalffy B, Armstrong DL \& Zoghbi HY (2002). Insight into Rett syndrome: MeCP2 levels display tissue-and cell-specific differences and correlate with neuronal maturation. Hum Mol Genet 11(2): 115-124.

6. McLaren J \& Bryson SE (1987). Review of recent epidemiological studies of mental retardation: prevalence, associated disorders, and etiology. Am J Mental Retard 92(3): 243-254.

7. Stevenson RE \& Schwartz CE (2002). Clinical and molecular contributions to the understanding of X-linked mental retardation. Cytogenet Genom Res 99(14): 265-275.

8. Chelly J \& Mandel JL (2001). Monogenic causes of X-linked mental retardation. Nat Revis Genet 2(9): 669680.
9. Chelly J, Khelfaoui M, Francis F, Chérif B, \& Bienvenu T (2006). Genetics and pathophysiology of mental retardation. Europ J Hum Genet 14(6): 701-713.

10. Quaderi NA, Meehan RR, Tate PH, Cross SH, Bird AP, Chatterjee A \& Brown SDM (1994). Genetic and physical mapping of a gene encoding a methyl $\mathrm{CpG}$ binding protein, Mecp2, to the mouse $\mathrm{X}$ chromosome. Genomics 22(3): 648-651.

11. Nan X, Campoy FJ \& Bird A (1997). $\mathrm{MeCP} 2$ is a transcriptional repressor with abundant binding sites in genomic chromatin. Cell 88(4): 471-481.

12. Tate P, Skarnes W \& Bird A (1996). The methyl-CpG binding protein $\mathrm{MeCP} 2$ is essential for embryonic development in the mouse. Nat Gene 12(2): 205-208.

13. Fuks F, Hurd PJ, Wolf D, Nan X, Bird AP \& Kouzarides T (2003). The methylCpG-binding protein MeCP2 links DNA methylation to histone methylation. $J$ Biol Chem 278(6): 4035-4040.

14. Sheikh TI, Harripaul R, Ayub M \& Vincent JB (2018). MeCP2 AT-Hook1 mutations in patients with intellectual disability and/or schizophrenia disrupt DNA binding and chromatin compaction in vitro. Hum Muta 39(5): 717-728.

15. Young J I, Hong E P, Castle JC, CrespoBarreto J, Bowman AB, Rose MF \& Zoghbi HY (2005). Regulation of RNA splicing by the methylation-dependent transcriptional repressor methyl-CpG binding protein 2. Proc Natl Acad Sci 102(49): 17551-17558.

16. Hoffbuhr KC, Moses LM, Jerdonek MA, Naidu S \& Hoffman EP (2002). Associations between $\mathrm{MeCP} 2$ mutations, X-chromosome inactivation, and phenotype. Mental Retardation And Devel Disabilities Res Rev 8(2): 99-105.

17. Weaving LS, Williamson SL, Bennetts B, Davis M, Ellaway CJ, Leonard H \& 
Christodoulou J (2003). Effects of MECP2 mutation type, location and Xinactivation in modulating Rett syndrome phenotype. Am J Med Genet Part A 118(2): 103-114.

18. Akbarian S, Chen RZ, Gribnau J, Rasmussen TP, Fong HF, Jaenisch R \& Jones EG (2001). Expression pattern of the Rett syndrome gene MeCP2 in primate prefrontal cortex. Neurobiol Dise 8(5): 784-791.

19. Amir RE, Van den Veyver IB, Wan M, Tran CQ, Francke U \& Zoghbi HY (1999). Rett syndrome is caused by mutations in X-linked MECP2, encoding methyl-CpG-binding protein 2. Nat Genet 23(2): 185-188.

20. Raizis AM, Saleem M, MacKay R \& George PM (2009). Spectrum of MECP2 mutations in New Zealand Rett syndrome patients. New Zealand Med J 5(122): 1296.

21. Christodoulou J, Grimm A, Maher T \& Bennetts B (2003). RettBASE: the IRSA MECP2 variation database - a new mutation database in evolution. Hum Muta 21(5): 466-472.

22. Cheadle JP, Gill H, Fleming N, Maynard $\mathrm{J}$, Kerr A, Leonard $\mathrm{H}$ \& Hughes $\mathrm{H}$ (2000). Long-read sequence analysis of the MECP2 gene in Rett syndrome patients: correlation of disease severity with mutation type and location. Hum Mol Genet 9(7): 1119-1129.

23. Whatley SD, Puy H, Morgan RR, Robreau AM, Roberts AG, Nordmann Y \& Deybach JC (1999). Variegate porphyria in Western Europe: identification of PPOX gene mutations in 104 families, extent of allelic heterogeneity, and absence of correlation between phenotype and type of mutation. Am J Hum Genet 65(4): 984-994.

24. Dragich J, Houwink-Manville I \& Schanen C (2000). Rett syndrome: a surprising result of mutation in
MECP2. Hum Mol Genet 9(16): 23652375.

25. Ibrahim S \& Khan SG (2008). Rett syndrome: A classic presentation. $J$ Pediatric Neurol 6(2): 191-194.

26. Armstrong D, Dunn J K, Antalffy B \& Trivedi R (1995). Selective dendritic alterations in the cortex of Rett syndrome. J Neuropath \& Experimnt Neurol 54(2): 195-201.

27. Belichenko PV, Oldfors A, Hagberg B \& Dahlström A (1994). Rett syndrome: 3D confocal microscopy of cortical pyramidal dendrites and afferents. Neuroreport: Int J Rapid Communi Res Neurosci 5(12):15091513.

28. Chapleau CA, Calfa GD, Lane MC, Albertson AJ, Larimore JL., Kudo S \& Pozzo-Miller L (2009). Dendritic spine pathologies in hippocampal pyramidal neurons from Rett syndrome brain and after expression of Rett-associated MECP2 mutations. Neurobiol Dise 35(2): 219-233.

29. Blue ME, Naidu S \& Johnston MV (1999). Altered development of glutamate and GABA receptors in the basal ganglia of girls with Rett syndrome. Experiment Neurol 156(2): 345-352.

30. Frints SGM, Froyen G, Marynen P \& Fryns JP (2002). X-linked mental retardation: vanishing boundaries between non-specific (MRX) and syndromic (MRXS) forms. Clini Genet 62(6): 423-432.

31. Hardwick SA, Reuter K, Williamson SL., Vasudevan V, Donald J, Slater K \& Smith RL (2007). Delineation of large deletions of the MECP2 gene in Rett syndrome patients, including a familial case with a male proband. Euro J Hum Genet 15(12): 1218-1229.

32. Hagberg B, Aicardi J, Dias K \& Ramos O (1983). A progressive syndrome of 
autism, dementia, ataxia, and loss of purposeful hand use in girls: Rett's syndrome: report of 35 cases. Annal Neurol: Offic J Am Neurol Associat Child Neurol Soci 14(4): 471-479.

33. Zahorakova D, Rosipal R, Hadac J, Zumrova A, Bzduch V, Misovicova N \& Martasek P (2007). Mutation analysis of the MECP2 gene in patients of Slavic origin with Rett syndrome: novel mutations and polymorphisms. J Hum Genet 52(4): 342-348.

34. Ballestar E, Yusufzai TM \& Wolffe AP (2000). Effects of Rett syndrome mutations of the methyl-CpG binding domain of the transcriptional repressor MeCP2 on selectivity for association with methylated DNA. Biochem 39(24): 7100-7106.

35. Wan M, Lee S SJ, Zhang X, HouwinkManville I, Song HR, Amir RE \& Zoghbi HY (1999). Rett syndrome and beyond: recurrent spontaneous and familial MECP2 mutations at $\mathrm{CpG}$ hotspots. The Am J Hum Genet 65(6): 1520-1529.

36. Rett A (1966). On a unusual brain atrophy syndrome in hyperammonemia in childhood. Wiener Medizinische Wochenschrift (1946) 116(37): 723.

37. Kirby RS, Lane JB, Childers J, Skinner SA, Annese F, Barrish JO \& Percy AK (2010). Longevity in Rett syndrome: analysis of the North American Database. J Pedia 156(1): 135-138.

38. Luikenhuis S, Giacometti E, Beard CF \& Jaenisch R (2004). Expression of MeCP2 in postmitotic neurons rescues Rett syndrome in mice. Proc Natl Acad Sci 101(16): 6033-6038.

39. Amir R E, Sutton VR \& Van den Veyver IB (2005). Newborn screening and prenatal diagnosis for Rett syndrome: implications for therapy. $J$ Child Neurol 20(9): 779-783.
40. Iqbal Z \& Van Bokhoven H (2014). Identifying genes responsible for intellectual disability in consanguineous families. Hum Hered 77(1-4): 150-160.

41. Bibi R, Maqbool A, Khan S \& Khan J (2018). Microcephaly-A Neurodevelopmental Hereditary Disorder with Emerging Drifts of Zikv. FUUAST J Biol 8(1): 123-132.

42. Hussain R \& Bittles AH (1998). The prevalence and demographic characteristics of consanguineous marriages in Pakistan. $J$ Biosociol Sci 30(2): 261-275..

43. Brent RL (2004). Environmental causes of human congenital malformations: the pediatrician's role in dealing with these complex clinical problems caused by a multiplicity of environmental and genetic

factors. Pediatric 113(Supplement 3): 957-968.

44. Hunter AG (2000). Outcome of the routine assessment of patients with mental retardation in a genetics clinic. Am J Medi Genet 90(1): 60-68.

45. Kleefstra T \& Hamel BCJ (2005). Xlinked mental retardation: further lumping, splitting and emerging phenotypes. Clin Genet 67(6): 451-467.

46. Bahi-Buisson N, Nectoux J, RosasVargas H, Milh M, Boddaert N, Girard B \& Héron D (2008). Key clinical features to identify girls with CDKL5 mutations. Brain 131(10): 2647-2661.

47. Neul JL, Kaufmann WE, Glaze DG, Christodoulou J, Clarke AJ, BahiBuisson N \& Renieri A (2010). Rett syndrome: revised diagnostic criteria and nomenclature. Annal Neurolo 68(6): 944-950.

48. Chailangkarn T, Acab A \& Muotri AR (2012). Modeling neurodevelopmental disorders using human neurons. Curr Opin Neurobiol 22(5): 785-790. 
49. Ahmed I (2015). Mapping of Genes Involved in Neurological Disorders in Pakistani Families (Docto dissert, Nati Uni Sci \& Techno Islamab-Pak).

50. Cheung AY, Horvath LM, Grafodatskaya D, Pasceri P, Weksberg R, Hotta A \& Ellis J (2011). Isolation of MECP2-null Rett Syndrome patient hiPS cells and isogenic controls through $\mathrm{X}$-chromosome inactivation. Hum Molecul Genet 20(11): 2103-2115.

51. Marchetto MC, Carromeu C, Acab A, Yu D, Yeo GW, Mu Y \& Muotri AR (2010). A model for neural development and treatment of Rett syndrome using human induced pluripotent stem cells. Cell 143(4): 527-539.

52. Walsh RM \& Hochedlinger K (2010). Modeling Rett syndrome with stem cells. Cell 143(4): 499-500.

53. Ananiev G, Williams EC, Li H \& Chang $Q$ (2011). Isogenic pairs of wild type and mutant induced pluripotent stem cell (iPSC) lines from Rett syndrome patients as in vitro disease model. PloS One 6(9): e25255.

54. Kim KY, Hysolli E \& Park IH (2011). Neuronal maturation defect in induced pluripotent stem cells from patients with Rett syndrome. Proc Natl Acad Sci 108(34): 14169-14174.

55. Tropea D, Giacometti E, Wilson NR, Beard C, McCurry C, Fu DD \& Sur M (2009). Partial reversal of Rett Syndrome-like symptoms in $\mathrm{MeCP} 2$ mutant mice. Proc Natl Acad Sci 106(6): 2029-2034.

56. Kang HJ, Kawasawa YI, Cheng F, Zhu Y, Xu X, Li M \& Guennel T (2011).
Spatio-temporal transcriptome of the human brain. Nature 478(7370): 483489.

57. Colantuoni C, Lipska BK., Ye T, Hyde TM, Tao R, Leek JT \& Kleinman JE (2011). Temporal dynamics and genetic control of transcription in the human prefrontal cortex. Nature 478(7370): 519-523.

58. Ormazabal A, Artuch R, Vilaseca MA, Aracil A \& Pineda M (2005). Cerebrospinal fluid concentrations of folate, biogenic amines and pterins in Rett syndrome: treatment with folinic acid. Neuro Pediatric 36(06): 380-385.

59. Jung BP, Jugloff DG, Zhang G, Logan R, Brown S \& Eubanks JH (2003). The expression of methyl $\mathrm{CpG}$ binding factor MeCP2 correlates with cellular differentiation in the developing rat brain and in cultured cells. J Neuro Biol 55(1): 86-96.

60. Harvey CG, Menon SD, Stachowiak B, Noor A, Proctor A, Mensah AK \& Kennedy JL (2007). Sequence variants within exon 1 of MECP2 occur in females with mental retardation. Am $J$ Med Gene Part B: Neuropsychia Gene 144(3): 355-360.

61. Fehr S, Bebbington A, Nassar N, Downs J, Ronen G. M, De Klerk N \& Leonard $H$ (2011). Trends in the diagnosis of Rett syndrome in Australia. Pediatric Res 70(3): 313-319.

62. Fehr S, Bebbington A, Nassar N, Downs J, Ronen GM, De Klerk N \& Leonard H (2011). Trends in the diagnosis of Rett syndrome in Australia. Pediatric Res 70(3): 313-319. 